\title{
Pengaruh Penambahan Ca(NO3)2 Terhadap Hasil Tanaman Selada Kriting (Lactuca Sativa L.) pada Sistem Hidroponik Deep Flow Technique (DFT)
}

\section{NI NYOMAN SURYANTINI, GEDE WIJANA*), DAN RINDANG DWIYANI}

Program Studi Agroekoteknologi Fakultas Pertanian Universitas Udayana

Jl. P. B. Sudirman Denpasar Bali 80232

${ }^{*}$ E-mail: wijana07@gmail.com

\begin{abstract}
The Effect of Addition of $\mathrm{Ca}\left(\mathrm{NO}_{3}\right)_{2}$ to the Results of Lettuce (Lactuca sativa L.) in the Hydroponic System of Deep Flow Technique (DFT). Plants, in general, require composition, concentration, and volume of nutrient solutions which different depends on the type and phase of plant growth. Leaf vegetable crops such as lettuce (Lactuca sativa $\mathrm{L}$.) require higher Nitrogen $(\mathrm{N})$ nutrients than other vegetable crops, but the problem we faced at the moment is the hydroponic nutrients that are traded only in the general form of nutrient, therefore the addition of $\mathrm{N}$ nutrients in the form of calcium nitrate $\left(\mathrm{Ca}\left(\mathrm{NO}_{3}\right)_{2}\right)$ needs to be done to meet the needs of lettuce plants. This study was aimed to determine the effect of the addition of $\mathrm{Ca}\left(\mathrm{NO}_{3}\right)_{2}$ and to find the optimum dosage of the addition of $\mathrm{Ca}\left(\mathrm{NO}_{3}\right)_{2}$ to the general hydroponic nutrition of vegetables on lettuce use DFT hydroponic system. The treatments consisted of five levels which are nutrition $\mathrm{AB}$ Mix general vegetable as a control, and nutrition $\mathrm{AB}$ Mix with the addition of $30 \mathrm{~g}, 60 \mathrm{~g}, 90 \mathrm{~g}$, and $120 \mathrm{~g} \mathrm{Ca}\left(\mathrm{NO}_{3}\right)_{2}$. The results of the observation showed that the treatment of the addition of $\mathrm{Ca}\left(\mathrm{NO}_{3}\right)_{2}$ fertilizer had a very significant effect on all observed variables, except for the diameter of the lettuce plant. The optimum addition of $\mathrm{Ca}\left(\mathrm{NO}_{3}\right)_{2}$ for lettuce was found at $90.04 \mathrm{~g}$ with a maximum yield of 207.92 g.
\end{abstract}

Keywords: DFT, AB Mix general vegetable, Ca(NO3)2, Lettuce (Lactuca sativa L.)

\section{PENDAHULUAN}

Hidroponik merupakan teknologi penumbuhan dan pengembangan tanaman pada media air atau media pengganti tanah, yang diperkaya larutan hara (Roidah, 2014; Wahyuningsih et al., 2016). Keuntungan dari hidroponik yaitu efisien terhadap penggunaan lahan, lebih mudah dan praktis dalam penerapannya, serta mampu meningkatkan kualitas dan kuantitas hasil produksi tanaman (Asaduzzman et al., 2015). Tanaman yang dapat dibudidayakan dengan teknik hidroponik yaitu tanaman umur pendek salah satunya selada (Roidah, 2014). 


\section{NI NYOMAN SURYANTINI. et al. Pengaruh Penambahan Ca(NO3)2 Terhadap Hasil...}

Ginting (2010) menyatakan bahwa tanaman selada merupakan tanaman yang memiliki nilai ekonomis tinggi, namun disisi lain peka terhadap kondisi lingkungan yang ekstrim, sehingga teknik hidroponik merupakan teknik yang sesuai untuk tanaman selada.

Teknik hidroponik menurut jenis media yang digunakan ada dua yaitu teknik substrat (agregat) dan teknik kultur air (Relf, 2009). Kedua teknik ini dapat dikombinasikan sesuai kebutuhan di lapangan, salah satunya dengan penambahan media arang sekam pada teknik Deef Flow Tehnique (DFT) (Sastro dan Rokhmah, 2016).

Nutrisi merupakan bagian yang sangat penting dalam proses budidaya tanaman secara hidroponik. Nutrisi yang umum dipergunakan pada saat ini yaitu dalam bentuk $\mathrm{AB}$ mix general sayur, dengan kandungan unsur hara lengkap, yaitu unsur hara makro dan mikro (Purbajati et al., 2017).

Furoidah (2018) menyatakan bahwa kebutuhan unsur hara dari setiap tanaman berbeda-beda tergantung jenis dan fase pertumbuhan tanaman, tanaman sayuran daun umumnya membutuhkan unsur hara nitrogen yang lebih tinggi dibandingkan tanaman buah dan bunga.

Penambahan unsur hara nitrogen untuk tanaman hidroponik hanya tersedia dalam bentuk pupuk majemuk yaitu $\mathrm{KNO}_{3}$ (kalium nitrat) dan $\mathrm{Ca}\left(\mathrm{NO}_{3}\right)_{2}$ (kalsium nitrat), sehingga penambahan satu jenis pupuk akan mempengaruhi dua unsur hara sekaligus (Sastro dan Rokhmah, 2016)

Handayanto et al., 2017 Unsur hara kalsium merupakan unsur hara yang sangat berperan dalam pembentukan titik-titik tumbuh tanaman, seperti pucuk baru dan ujung akar, serta berperan dalam pembentukan daun dan memiliki kemampuan untuk meningkatkan penyerapan nitrogen dalam bentuk nitrat pada tanaman). Lebih lanjut hasil penelitian pendahuluan Suryantini (2018) juga menemukan bahwa penambahan pupuk kalsium nitrat pada nutrisi $\mathrm{AB}$ Mix general sayur mampu meningkatkan pertumbuhan dan hasil tanaman selada kriting pada teknik hidroponik DFT yang ditambahkan media arang sekam.

Pentingnya unsur hara nitrogen dan kalsium bagi pertumbuhan tanaman sayuran daun mendorong adanya modifikasi unsur hara dengan penambahan pupuk kalsium nitrat pada nutrisi $\mathrm{AB}$ Mix general sayur, yang akan diterapkan pada tanaman selada kriting sebagai sampelnya.

\section{BAHAN DAN METODE}

Penelitian ini dilaksanakan pada green house yang terletak di Banjar Selantang, Desa 
Belok Sidan, Kecamatan Petang, Kabupaten Badung, Bali. Banjar Selantang merupakan daerah yang berada pada ketinggian 1500 mdpl, dengan suhu rata-rata harian $24^{\circ} \mathrm{C}$, sedangkan untuk analisis persentase $\mathrm{N}$ jaringan daun dilaksanakan pada laboratorium Agronomi dan Hortikultura Fakultas Pertanian dan dibantu oleh laboratorium Analisis Pangan Fakultas Teknologi Pertanian Universitas Udayana, Jalan PB Sudirman, Denpasar. Penelitian ini dilaksanakan dari bulan Januari sampai dengan bulan Maret 2019 .

Alat yang dipergunakan meliputi tiga unit instalasi yang berukuran 9,5 m x $2 \mathrm{~m}$, timbangan, penggaris, EC meter, $\mathrm{pH}$ meter, jangka sorong, dan klorofil meter SPAD-502 plus. Bahan yang digunakan yaitu benih selada kriting green rapid (merek panah merah), arang sekam, rock woll, air baku, pupuk $\mathrm{Ca}\left(\mathrm{NO}_{3}\right)_{2}$ dan nutrisi $\mathrm{AB}$ Mix.

Penelitian ini menggunakan rancangan acak lengkap (RAL) yang terdiri dari lima taraf perlakuan yaitu: nutrisi $\mathrm{AB}$ mix general sayur $\left(\mathrm{P}_{1}\right)$, nutrisi $\mathrm{AB}$ mix $+30 \mathrm{~g} \mathrm{Ca}\left(\mathrm{NO}_{3}\right)_{2}$ $\left(\mathrm{P}_{2}\right)$, nutrisi $\mathrm{AB} \operatorname{mix}+60 \mathrm{~g} \mathrm{Ca}\left(\mathrm{NO}_{3}\right)_{2}\left(\mathrm{P}_{3}\right)$, nutrisi $\mathrm{AB}$ mix $+90 \mathrm{~g} \mathrm{Ca}\left(\mathrm{NO}_{3}\right)_{2}\left(\mathrm{P}_{4}\right)$ dan nutrisi $\mathrm{AB}$ mix $+120 \mathrm{~g} \mathrm{Ca}\left(\mathrm{NO}_{3}\right)_{2}\left(\mathrm{P}_{5}\right)$. Perlakuan tersebut diulang sebanyak lima kali, dengan jumlah 40 tanaman dalam satu ulangan dan 200 tanaman dalam satu perlakuan.

Pelaksanaan penelitian diawali dengan persiapan instalasi kemudian dilanjutkan dengan persiapan bibit, peracikan nutrisi, pemberian perlakuan, perawatan, pengamatan dan analisis data.

Istalasi yang disiapkan adalah instalasi hidroponik sistem DFT dengan air tersirkulasi selama 24 jam menggunakan pompa aquarium Halico 103, dengan kapasitas debit air 1300/jam. Instalasi yang dipergunakan terbuat dari pipa PVC ukuran tiga dim, dengan ketinggian air yang dipertahankan diangka 2 $\mathrm{cm}$ dari dasar pipa. Jarak antara lubang pipa $20 \mathrm{~cm}$, jarak antara pipa $20 \mathrm{~cm}$, dan lubang pipa berukuran $5,4 \mathrm{~cm}$.

Bibit yang dipergunakan dalam penelitian ini adalah bibit yang telah dilakukan proses persemaian terlebih dahulu pada media arang sekam, hingga benih berkecambah. Kecambah yang telah berumur tujuh hari setelah semai (HSS), kemudian dipindahkan pada media rock woll yang berukuran $2,5 \mathrm{~cm} \times 2,5 \mathrm{~cm} \times 2,5 \mathrm{~cm}$ dan diletakkan pada baki (tray) yang berukuran 50 $\mathrm{cm}$ x $30 \mathrm{~cm}$ x 4,2 $\mathrm{cm}$ dan diletakkan pada tempat dengan pencahayaan penuh hingga muncul dua daun sejati.

Persiapan nutrisi dilakukan dengan menimbang pupuk kalsium nitrat sesuai 


\section{NI NYOMAN SURYANTINI. et al. Pengaruh Penambahan Ca(NO3)2 Terhadap Hasil...}

perlakuan yaitu sebanyak $30 \mathrm{~g}, 60 \mathrm{~g}, 90 \mathrm{~g}$, dan $120 \mathrm{~g}$ per satu liter larutan stok. Pupuk kalsium nitrat yang telah ditimbang kemudia ditambahkan pada masing-masing stok A nutrisi $\mathrm{AB}$ mix general sayur, yang telah dipersiapkan sebelumnya. Pupuk yang telah ditambahkan dan dikelompokkan sesuai perlakuan, kemudian diencerkan menggunakan air demineralisasi (0 ppm) menjadi satu liter larutan stok, dan diletakkan pada jerigen penyimpanan stok A. Stok B dari nutrisi $\mathrm{AB}$ mix general sayur juga dilarutkan dan disimpan pada jerigen stok B seperti yang dilakukan pada stok A namun, tidak ditambahkan dengan pupuk kalsium nitrat. Jumlah nutrisi yang dipergunakan selama perlakuan yaitu sebanyak lima liter.

Penanaman dilakukan pada gelas plastik yang telah dilubangi, kemudian ditambahkan arang sekam setengah bagian, lalu ditanami bibit selada kriting yang telah memiliki dua daun sejati dan kembali ditambahkan arang sekam untuk menyangga bibit agar tidak rebah. Bibit tersebut kemudian dipindahkan kedalam instalasi hidroponik yang telah dialirkan nutrisi dengan konsentrasi $300 \mathrm{ml} / 801$ larutan stok A dan B sesuai perlakuan, dengan $\mathrm{pH}$ yang dipertahankan pada angka 5,5-6,5.

Perawatan yang dilakukan adalah perawatan tanaman, debit air dan ketersediaan nutrisi bagi tanaman, yang dilakukan setiap tiga hari sekali dan pada saat melakukan pengamatan.

Pengamatan dilakukan setelah tanaman berumur $7,14,21$, dan 28 hari setelah tanam (HST), serta dilakukan pemanenan pada saat tanaman berumur 28 HST. Tanaman yang diamati adalah tanaman sampel dari setiap perlakuan. Penetapan tanaman sempel dilakukan dengan cara memilih tanaman yang berada pada bagian tengah instalasi (tanaman yang terhitung setelah tanaman nomber sepuluh dari depan dan sepuluh dari belakang) tanaman yang berada pada bagian tengah tersebut kemudian dipilih secara rendem.

Variabel yang diamati meliputi tinggi tanaman, luas permukaan tajuk, kandungan klorofil daun, panjang akar terpanjang, panjang batang, diameter batang, berat segar akar, berat segar tajuk, berat segar total dan persentase $\mathrm{N}$ jaringan daun.

Keseluruhan data hasil penelitian dianalisis statistik sesuai dengan rancangan acak lengkap, kecuali variabel persentase $\mathrm{N}$ jaringan daun, karena sempel yang diamati bersifat komposit.

Perlakuan yang berpengaruh nyata dilanjutkan dengan uji BNT taraf $5 \%$, serta untuk mengetahui dosis optimum dari penambahan pupuk kalsium nitrat dilakukan 
uji regresi pada hasil pengukuran berat segar tajuk tanam selada kriting.

\section{HASIL DAN PEMBAHASAN}

Hasil analisis statistik menunjukkan bahwa, perlakuan penambahan pupuk $\mathrm{Ca}\left(\mathrm{NO}_{3}\right)_{2}$ pada nutrisi “AB mix general sayur" berpengaruh sangat nyata $(\mathrm{p}<0,01)$ terhadap semua variabel yang diamati, kecuali diameter batang (ns) (Tabel 1).

Tinggi tanaman selada kriting mengalami peningkatan akibat penambahan $\mathrm{Ca}\left(\mathrm{NO}_{3}\right)_{2}$, dengan hasil yang berbeda nyata antara perlakuan $\mathrm{P}_{1}$ dengan perlakuan yang lainnya, sedangkan perlakuan $\mathrm{P}_{2}$, dengan $\mathrm{P}_{3}$, $\mathrm{P}_{4}$, dan $\mathrm{P}_{5}$ menunjukkan hasil yang berbeda tidak nyata (Tabel 2).

Luas permukaan tajuk pada perlakuan $\mathrm{P}_{2}$ mengalami peningkatan sebesar $31,27 \%$ dan berbeda nyata dengan perlakuan yang lainnya. Luas permukaan tajuk mengalami peningkatan seiring dengan meningkatnya jumlah pupuk yang diberikan dan mencapai titik maksimum pada perlakuan $\mathrm{P}_{4}$ dengan hasil yang berbeda tidak nyata dengan perlakuan $\mathrm{P}_{3}$. Penambahan yang lebih tinggi pada perlakuan $\mathrm{P}_{5}$ menyebabkan penurunan luas permukaan tajuk tanaman selada kriting, dengan hasil yang berbeda nyata dengan perlakuan $\mathrm{P}_{4}$ dan berbeda tidak nyata dengan perlakuan $\mathrm{P}_{3}$.
Klorofil daun juga mengalami peningkatan seiring dengan penambahan jumlah pupuk yang diberikan dengan hasil yang berbeda nyata antara perlakuan $\mathrm{P}_{1}$ dengan perlakuan yang lainnya. Perlakuan $\mathrm{P}_{2}$ menunjukkan hasil yang berbeda nyata dengan perlakuan $\mathrm{P}_{4}$ dan $\mathrm{P} 5$, namun berbeda tidak nyata dengan perlakuan $\mathrm{P}_{3}$. Perlakuan $\mathrm{P}_{3}$ juga menunjukkan hasil yang berbeda tidak nyata dengan perlakuan $\mathrm{P}_{4}$ dan $\mathrm{P}_{5}$ (Tabel 2).

Panjanag batang tanaman selada kriting meningkat akibat penambahan pupuk $\mathrm{Ca}\left(\mathrm{NO}_{3}\right)_{2}$ yang diaplikasikan, dengan hasil yang berbeda nyata antara perlakuan $\mathrm{P}_{1}$ dengan perlakuan yang lainnya. Hasil tertinggi diperoleh dari perlakuan $\mathrm{P}_{2}$, sedangkan panjang batang tanaman selada kriting pada penambahan jumlah pupuk dari perlakuan $\mathrm{P}_{2}$ ke $\mathrm{P}_{3}$ cenderung mengalami penurunan dan berbeda tidak nyata dengan perlakuan $\mathrm{P}_{4}$, dan $\mathrm{P}_{5}$ (Tabel 2).

Panjang akar terpanjang mengalami peningkatan akibat perlakuan $\mathrm{P}_{3}$ dan $\mathrm{P}_{4}$ dengan hasil yang berbeda tidak nyata. Perlakuan $\mathrm{P}_{4}$ berbeda tidak nyata dengan perlakuan $\mathrm{P}_{1}$ dan $\mathrm{P}_{5}$, dan berbeda nyata dengan perlakuan $\mathrm{P}_{2}$, sedangkan perlakuan $\mathrm{P}_{2}$ berbeda tidak nyata dengan perlakuan $\mathrm{P}_{1}$ dan $\mathrm{P}_{5}$ (Tabel 3).

Berat segar akar tanaman selada kriting cenderung mengalami peningkatan 


\section{NI NYOMAN SURYANTINI. et al. Pengaruh Penambahan Ca(NO3)2 Terhadap Hasil...}

pada perlakuan $\mathrm{P}_{3}$ dan $\mathrm{P}_{4}$, namun tidak secara berbeda nyata dengan perlakuan $\mathrm{P}_{2}$ dan $\mathrm{P}_{5}$ signifikan sehingga tidak berbeda nyata (Tabel 3).

dengan perlakuan $\mathrm{P}_{1}$. Perlakuan $\mathrm{P}_{1}$ juga tidak

Tabel 1. Signifikansi Penambahan $\mathrm{Ca}\left(\mathrm{NO}_{3}\right)_{2}$ pada Nutrisi $\mathrm{AB}$ Mix General Sayur terhadap Pertumbuhan dan Hasil Tanaman Selada Kriting

\begin{tabular}{lll}
\hline No & Parameter yang diamati & Perlakuan \\
\hline 1 & Tinggi tanaman $(\mathrm{cm})$ & $* *$ \\
2 & Luas permukaan tajuk $\left(\mathrm{cm}^{2}\right)$ & $* *$ \\
3 & Kandungan klorofil daun & $* *$ \\
4 & Panjang akar terpanjang $(\mathrm{cm})$ & $* *$ \\
5 & Panjang batang $(\mathrm{cm})$ & $* *$ \\
6 & Diameter batang $(\mathrm{mm})$ & Ns \\
7 & Berat segar akar $(\mathrm{g})$ & $* *$ \\
8 & Berat segar tajuk $(\mathrm{g})$ & $* *$ \\
9 & Beratsegar total $(\mathrm{g})$ & $* *$ \\
\hline & Keterangan : ns $\quad=$ berpengaruh tidak nyata $(\mathrm{p} \geq 0,05)$ &
\end{tabular}

Tabel 2. Pengaruh Penambahan Pupuk Kalsium Nitrat $\left(\mathrm{Ca}\left(\mathrm{NO}_{3}\right)_{2}\right)$ terhadap Tinggi Tanaman, Luas Permukaan Tajuk, dan Indikator Klorofil Daun

\begin{tabular}{cccccc}
\hline Perlakuan & $\begin{array}{c}\text { Tinggi } \\
\text { Tanaman } \\
(\mathrm{cm})\end{array}$ & $\begin{array}{c}\text { Luas } \\
\text { Permukaan } \\
\text { Tajuk }\left(\mathrm{cm}^{2}\right)\end{array}$ & $\begin{array}{c}\text { Indikator } \\
\text { Klorofil Daun } \\
(\text { SPDA })\end{array}$ & $\begin{array}{c}\text { Diameter } \\
\text { Batang } \\
(\mathrm{cm})\end{array}$ & $\begin{array}{c}\text { Panjang } \\
\text { Batang } \\
(\mathrm{cm})\end{array}$ \\
\hline P1 & $23,67 \mathrm{~b}$ & $433,01 \mathrm{~d}$ & $14,78 \mathrm{c}$ & $1,21 \mathrm{a}$ & $1,67 \mathrm{c}$ \\
P2 & $34,47 \mathrm{a}$ & $568,39 \mathrm{c}$ & $15,90 \mathrm{~b}$ & $1,27 \mathrm{a}$ & $2,74 \mathrm{a}$ \\
P3 & $33,47 \mathrm{a}$ & $883,68 \mathrm{ab}$ & $16,18 \mathrm{ab}$ & $1,35 \mathrm{a}$ & $2,12 \mathrm{~b}$ \\
P4 & $33,47 \mathrm{a}$ & $887,25 \mathrm{a}$ & $16,90 \mathrm{a}$ & $1,39 \mathrm{a}$ & $2,28 \mathrm{~b}$ \\
P5 & $35,33 \mathrm{a}$ & $735,18 \mathrm{~b}$ & $16,98 \mathrm{a}$ & $1,13 \mathrm{a}$ & $2,30 \mathrm{~b}$ \\
\hline BNT 5\% & 2,44 & 135,93 & 0,91 & Ns & 0,42 \\
\hline
\end{tabular}

Keterangan : Angka yang diikuti huruf yang berbeda pada perlakuan dan kolom yang sama menunjukkan berbeda nyata pada uji BNT taraf $5 \%$. 
Tabel 3. Pengaruh Penambahan Pupuk Kalsium Nitrat $\left(\mathrm{Ca}\left(\mathrm{NO}_{3}\right)_{2}\right)$ Terhadap Berat Segar Akar, Berat Segar Tajuk, Berat Segar Total dan N Jaringan Daun

\begin{tabular}{cccccc}
\hline Perlakuan & $\begin{array}{c}\text { Panjang } \\
\text { Akar } \\
\text { Terpanjang } \\
(\mathrm{cm})\end{array}$ & $\begin{array}{c}\text { Berat } \\
\text { Segar Akar } \\
(\mathrm{g})\end{array}$ & $\begin{array}{c}\text { Berat } \\
\text { Segar } \\
\text { Tajuk } \\
(\mathrm{g})\end{array}$ & $\begin{array}{c}\text { Berat Segar } \\
\text { Total } \\
(\mathrm{g})\end{array}$ & $\begin{array}{c}\text { N Jaringan } \\
\text { Daun } \\
(\%) \\
*\end{array}$ \\
\hline P1 & $32,67 \mathrm{bc}$ & $20,26 \mathrm{ab}$ & $149,87 \mathrm{c}$ & $170,13 \mathrm{c}$ & 3,7393 \\
P2 & $30,53 \mathrm{c}$ & $17,40 \mathrm{~b}$ & $180,73 \mathrm{~b}$ & $198,07 \mathrm{~b}$ & 4,0506 \\
P3 & $42,93 \mathrm{a}$ & $22,47 \mathrm{a}$ & $192,00 \mathrm{ab}$ & $214,47 \mathrm{ab}$ & 4,1132 \\
P4 & $38,27 \mathrm{ab}$ & $23,83 \mathrm{a}$ & $209,00 \mathrm{a}$ & $232,83 \mathrm{a}$ & 4,2726 \\
P5 & $32,23 \mathrm{bc}$ & $17,33 \mathrm{~b}$ & $195,53 \mathrm{ab}$ & $212,87 \mathrm{ab}$ & 4,2927 \\
\hline BNT 5\% & 6,04 & 4,62 & 24,43 & 25,71 & \\
\hline
\end{tabular}

Keterangan : Angka-angka yang diikuti dengan huruf yang sama pada kolom yang sama menunjukkan perbedaan tidak nyata pada Uji BNTtaraf 5\%

*: tidak di analisis statistik

Berat segar total tanaman pada perlakuan $\mathrm{P}_{1}$ menunjukkan hasil terendah yang hanya mencapai $170,13 \mathrm{~g}$ dan berbeda nyata dengan perlakuan yang lainnya. Perlakuan $\mathrm{P}_{2}$ mampu meningkatkan berat segar total sejumlah 27,94 $\mathrm{g}$ dan berbeda tidak nyata dengan perlakuan $\mathrm{P}_{3}$ dan $\mathrm{P}_{5}$. Berat segar total pada perlakuan $\mathrm{P}_{3}$ dan $\mathrm{P}_{5}$ juga tidak berbeda nyata dengan perlakuan $\mathrm{P}_{4}$, sedangakan perlakuan $\mathrm{P}_{4}$ berbeda nyata dengan perlakuan $\mathrm{P}_{2}$ dari hasil uji $\mathrm{BNT}$ taraf 5\% (Tabel 3).

Berat segar tajuk tanaman selada kriting, secara nyata mengalami peningkatan seiring dengan bertambahnya jumlah pupuk yang diberikan. Penambahan pupuk sejumlah $30 \mathrm{~g}, 60 \mathrm{~g}, 90 \mathrm{~g}$ dan $120 \mathrm{~g}$ mampu meningkatkan berat segar tajuk dengan nilai berturut-turut sebesar $20,59 \%, 28,11 \%$, sering mengendap dalam bentuk kristal
$39,45 \%$ dan 30,47 \%. Peningkatan berat segar tajuk didukung oleh peningkatan variabel luas permukaan tajuk tanaman, kandungan klorofil daun, panjang batang, panjang akar terpanjang dan berat segar akar. Lestari dan Aini (2018), menyatakan bahwa pertumbuhan tanaman tidak hanya dipengaruhi oleh satu variabel, namun setiap variabel akan saling terkait untuk mendukung pertumbuhan dan peningkatan hasil tanaman, pendapat tersebut sejalan dengan hasil penelitian yang diperoleh, dimana peningkatan berat segar akar pada penambahan $60 \mathrm{~g}$ dan $90 \mathrm{~g}$ ternyata mampu mempengaruhi hasil produksi tanaman selada kriting (Tabel 2).

Handayanto et al. (2017) menyatakan bahwa unsur hara kalsium merupakan unsur hara yang banyak terdapat dalam daun, dan 


\section{NI NYOMAN SURYANTINI. et al. Pengaruh Penambahan Ca(NO3)2 Terhadap Hasil...}

kalsium oksalat. Persentase kalsium terbesar terdapat pada dinding sel tepatnya pada lamela tengah, yang berperan dalam proses pembelahan dan pengaturan permiabilitas dalam sel serta mendukung pertumbuhan dan perkembangan akar tanaman. Almaida et al. (2018) juga menemukan bahwa penambahan unsur hara kalsium pada proses budidaya tanaman selada mampu meningkatkan panjang dan luas permukaan akar tanaman selada kriting.

Hasil penelitian pendahuluan Suryantini (2018) juga menemukan bahwa penambahan pupuk kalsium nitrat pada tanaman selada kriting dengan sistem hidroponik DFT, mampu meningkatkan luas permukaan daun, serta mampu meningkatkan berat segar tajuk dan berat segar total tanaman selada kriting, dibandingkan dengan perlakuan tanpa penambahan pupuk $\mathrm{Ca}\left(\mathrm{NO}_{3}\right)_{2}$.

Pupuk $\mathrm{Ca}\left(\mathrm{NO}_{3}\right)_{2}$ selain mengandung unsur hara kalsium, juga mengandung unsur hara nitrogen. Unsur hara nitrogen merupakan unsur hara yang berfungsi sebagai bahan sintesis klorofil, protein dan asam amino, serta berperan aktif dalam mengatur proses membuka dan menutupnya stomata (Kurniawan et al., 2017). Hal tersebut terlihat dari persentase kandungan nitrogen pada jaringan daun tanaman selada kriting.
Persentase kandungan nitrogen pada jaringan daun cenderung meningkat, seiring dengan penambahan pupuk yang diaplikasikan, peningkatan kandungan nitrogen ini juga berpengaruh terhadap peningkatan berat segar tajuk diperoleh. Berat segar tajuk tanaman selada kriting mengalami peningkatan seiring dengan penambahan pupuk $\mathrm{Ca}\left(\mathrm{No}_{3}\right)_{2}$ yang diaplikasikan. Penambahan pupuk sebanyak $30 \mathrm{~g}$ mampu meningkatkan berat segar tajuk tanaman sebesar $20,59 \%$, sedangkan penambahan pupuk dari $30 \mathrm{~g}$ ke $60 \mathrm{~g}$ dan $60 \mathrm{~g}$ ke $90 \mathrm{~g}$ berturut-turut mampu meningkatkan hasil sebesar $6,24 \%$, dan $8,85 \%$, sedangkan penambahan $90 \mathrm{~g}$ ke $120 \mathrm{~g}$ ternyata menyebabkan terjadinya penurunan hasil sebesar 6,44\%. Peningkatan hasil paling tinggi diperoleh dari penambahan pupuk sejumlah $30 \mathrm{~g}$, namun berat segar tajuk yang diperoleh lebih rendah dari penambahan pupuk sejumlah 60 g, 90 g, dan 120 g. Hal ini sejalan dengan hasil penelitian Siregar et al. (2015) yang menemukan bahwa, pemberian unsur hara $\mathrm{N}$ yang lebih tinggi dari pada unsur hara $\mathrm{P}$ dan $\mathrm{K}$ mampu meningkatkan pertumbuhan daun dan batang tanaman selada, yang dibudidayakan dengan teknik hidroponik sistem terapung (THST) termodifikasi.

Penambahan $\mathrm{Ca}\left(\mathrm{NO}_{3}\right)_{2}$ sejumlah $90 \mathrm{~g}$ mampu meningkatkan hasil produksi, diduga 
akibat dari kondisi dan ketersediaan unsur hara yang diberikan dalam keadaan seimbang dan sesuai dengan kebutuhan tanaman selada kriting. Pendapat tersebut sejalan dengan pendapat Purbajati et al. (2017) yang menyatakan bahwa usur hara yang dibutuhkan tanaman adalah unsur hara makro dan unsur hara mikro dengan konsentrasi seimbang dan sesuai dengan kebutuhan tanaman serta berada dalam kondisi lingkungan yang mendukung.

Penambahan $\mathrm{Ca}\left(\mathrm{NO}_{3}\right)_{2}$ yang lebih tinggi $(120 \mathrm{~g})$, cenderung mengalami penurunan hasil dari semua variabel yang diamati, kecuali pada Tinggi tanaman, kandungan klorofil daun, panjang bantang dan total $\mathrm{N}$ jaringan. Penurunan hasil tersebut diduga akibat dari terbentuknya larutan nutrisi yang tidak seimbang dan melebihi kebutuhan tanaman selada kriting, sehingga menghambat penyerapan unsur yang lainnya. Pendapat tersebut sejalan dengan pendapat Gorenjak dan Cencic (2013) yang menyatakan bahwa kandungan nitrogen dalam jumlah tinggi dapat menyebabkan terjadinya penyerapan yang berlebihan oleh tanaman, sehingga mengakibatkan ketidak seimbangan unsur hara. Kelebihan unsur hara nitrogen juga dapat menyebabkan gangguan pada proses metabolisme tanaman, serta dapat menyebabkan keracunan pada manusia yang mengkonsumsi tanaman tersebut.

Sarif et al. (2015) menyatakan bahwa unsur hara nitrogen merupakan unsur hara yang dominan dibutuhkan oleh tanaman sayuran daun. Kebutuhan unsur hara N tidak sama untuk setiap tanaman serta tidak dalam kondisi yang berlebihan atau kurang (optimum). Oleh karena itulah penambahan $\mathrm{Ca}\left(\mathrm{NO}_{3}\right)_{2}$ yang optimum perlu diketahui dengan uji regresi kuadratik dengan persamaan $y=-0,0066 x^{2}+1,1885 x+149,6$ dan $\mathrm{R}^{2}=0,9688$. Hasil uji regresi tersebut menunjukan bahwa penambahan pupuk $\mathrm{Ca}\left(\mathrm{NO}_{3}\right)_{2}$ yang optimum pada tanaman selada kriting yang dicobakan yaitu sebanyak 90,04 g dengan hasil berat segar tajuk maksimum sebesar 207,92 g.

Penambahan pupuk $\mathrm{Ca}\left(\mathrm{NO}_{3}\right)_{2}$ yang optimum dapat memberikan hasil yang maksimal yang didukung dari adanya pengoptimalan kerja jaringan meristem yang akan melakukan pembelahan, perpanjangan dan pembesaran sel, untuk membentuk dinding sel dan protoplasma. Pemenuhan kebutuhan unsur hara $\mathrm{N}$ juga akan menyebabkan terjadinya keseimbangan rasio antara akar dan daun, sehingga pertumbuhan vegetatif berjalan sempurna, sehingga akan berpengaruh terhadap pertumbuhan dan hasil yang diperoleh (Indrawan et al.,2018). 
NI NYOMAN SURYANTINI. et al. Pengaruh Penambahan Ca(NO3)2 Terhadap Hasil...

\section{SIMPULAN}

Berdasarkan hasil dan pembahasan maka dapat disimpulkan yaitu penambahan $\mathrm{Ca}\left(\mathrm{NO}_{3}\right)_{2}$ berpengaruh sangat nyata terhadap pertumbuhan dan hasil tanaman selada kriting, yang terlihat dari semua variabel yang diamati, kecuali pada variabel diameter batang. Hasil berat segar tajuk dan berat segar total tertinggi diperoleh dari penambahan $\mathrm{Ca}\left(\mathrm{NO}_{3}\right)_{2}$ sejumlah $90 \mathrm{~g}$ dan cenderung mengalami penurunan pada penambahan $60 \mathrm{~g}$ dan $120 \mathrm{~g}$, namun berbeda tidak nyata dari hasil uji lanjut yang dilakukan. Penambahan $\mathrm{Ca}\left(\mathrm{NO}_{3}\right)_{2}$ yang optimum pada nutrisi $\mathrm{AB}$ mix general sayur yaitu sebesar 90,04 g dengan hasil berat segar tajuk maksimum 207,92 g, yang diperoleh dari persamaan regresi kuadrattik $y=-0,0066 x^{2}+1,1885 x+149,6$ dan $R^{2}=0,9688$.

\section{DAFTAR PUSTAKA}

Almeida, P. H., A. F. Mogor, A. Z. Ribeiro, J. Heinrichs. and E. Amano. (2016). Increase in Lettuce (Lactuca sativa L.) Production by Foliar Calcium Application. Australia Journal Of Basic and Applied Sciences, 10(16):161-167.

Furoidah, N. (2018). Efektifitas Penggunaan AB Mix terhadap Pertumbuhan Beberapa Varietas Sawi (Brassica sp.). Fakultas Pertanian Universitas Jember, 2(1):A239-A246.

Ginting, C. (2010). Kajian Biologis Tanaman Selada dalam Berbagai Kondisi
Lingkungan pada Sistem Hidroponik. Agriplus, 02(02):101-113.

Gorenjak, H. A., and A. Cencic. (2013). Nitrate In Vegetables and Their Impact On Human Health. A Review. Acta Alimentaria, 42 (2): 158-172.

Handayanto. E., N. Mudarisma. dan A. Fiqri. (2017). Pengelolaan Kesuburan Tanah. UB Vres. Malang.

Indrawan, R. M., Y. Yafizham. dan S. Sutarno. (2018). Respon Tanaman Kedelai terhadap Pemupukan Kombinasi bio-slurry dengan Urea. J. Agro Complex, 2(1):36-42.

Krisna, B., E. T. S. Putra, R. Rogomulyo, D. Kastono. (2017). Pengaruh Pengayaan Oksigen dan Kalsium Terhadap Pertumbuhan Akar dan Hasil Selada Kriting (Lactuca sativa L.) pada Hidroponik Rakit Apung. Vegetalika, 6(4):14-27.

Kurniawan, A., T. Islami. dan Koesriharti. (2017). Pengaruh Aplikasi Pupuk N dan K Terhadap Pertumbuhan dan Hasil Tanaman Pakcoy (Barassica rapa var.chinensis) F1 Flaminggo. Jurnal Produksi Tanaman, 5(2):281-289.

Lestari, P. M. dan Aini. N. (2018). Komposisi Nutrisi dan Media Tanam Terhadap Pertumbuhan dan Hasil Tanaman Selada Romaine (Lactuca sativa. Var. romana L.) Sistem Hidroponik Substrat. Jurnal Produksi Tanaman, 6(3):455462.

Purbajanti, D. P., W. Slamet. dan F. Kusmiyanti. (2017). Hidroponik Bertanam Tanpa Tanah. EF Press Digimedia. Pondok Bukit Agung C-2 Sumurboto Banyumanik Semarang.

Relf, D. (2009). Home Hidroponics. Collage of Agriculture and Life Sciences, Virginia Polytechnic Institute and State University, Virginia Tech, Publication 426-084.

Roidah, I. S. (2014). Femanfaatan Lahan dengan Sistem Hidroponik. Jurnal 
Universitas Tulungagung Bonorowo, 1(2):143-150.

Sastro, Y. dan N. A. Rokhmah. (2016). Hidroponik Sayuran di Perkotaan. Balai Pengkajian Teknologi Pertanian (BPTP). Jakarta.

Sarif, P., A. Hadid. dan I. Wahyudi. 2015. Pertumbuhan dan Hasil Tanaman Sawi (Barassica juncea L.) akibat Pemberian Berbagai Dosis Pupuk Urea. e-J. Agrotecbis, 3(5): 585-591.

Siregar. J., S. Triyono. dan D. Suhandy. (2015). Pengujian Beberapa Nutrisi Hidroponik pada Selada (Lactuca sativa L.) dengan Hidroponik Sistem Terapung Termodifikasi(THST), 4(1):65-72.

Suryantini. (2018). Pengaruh Penambahan Konsentrasi Nutrisi dan Media Tanam Terhadap Pertumbuhan dan Hasil Tanaman Selada Kriting pada Hidroponik Substrat Sistem Deef Flow Technique (DPT). Elektif (Uji Pendahuluan)

Wahyuningsih, A., S. Fajriani. dan N. Aini. (2016). Komposisi Nutrisi dan Media Tanam terhadap Pertumbuhan dan Hasil Tanaman Pakcoy (Brassica rapa L.) Sistem Hidroponik. Jurnal Nutrisi Tanaman, 04(08):595-601. 